\title{
A new vesselless angiosperm stem with a cambial variant from the Upper Cretaceous of Antarctica
}

\author{
M. Laura Pipo, Ari Iglesias, and Josefina Bodnar \\ Acta Palaeontologica Polonica 65 (2), 2020: 261-272 doi:https://doi.org/10.4202/app.00697.2019
}

We sectioned a permineralized stem preserved in marine calcareous concretions from the Campanian (Upper Cretaceous) of James Ross Island, Antarctic Peninsula using the cellulose-acetate peel technique. The material is a slender stem displaying a combination of characters such as: (i) absence of vessels and axial parenchyma, (ii) presence of a cambial variant which produces axial vascular elements in segments (AVES pattern), and (iii) elongated upright ray cells. This character combination allows us to assign this fossil to family Chloranthaceae and to relate it to an extant genus Sarcandra. Consequently we describe Sarcandraxylon sanjosense gen. et sp. nov., representing the first vegetative fossil of Chloranthaceae-a basal angiosperm family with a fossil record extending back into the Early Cretaceous and dominated by pollen grains and a limited number of reproductive mesofossils. Besides doubtfully assigned leaves, there are no reported Cretaceous macrofossils of Chloranthaceae, which hinders our understanding of the overall pattern of morphological evolution for the family. The new fossil constitutes the first fossil occurrence of the Sarcandra clade in high latitudes of Western Gondwana. The particular wood anatomy and small diameter suggest a new plant habit (subshrub) for the physiognomy of the Cretaceous Antarctic floras.

Key words: Angiospermae, Chloranthales, Chloranthaceae, cambial variant, Campanian, Antarctica, James Ross Island.

M. Laura Pipo [laurapipo2@gmail.com] and Ari Iglesias [ari iglesias@yahoo.com.ar ], Instituto de Investigaciones en Biodiversidad y Medioambiente (INIBIOMA, CONICET-UNCOMA), Quintral 1250, (8400) San Carlos de Bariloche, Río Negro, Argentina. Josefina Bodnar [jbodnar@fcnym.unlp.edu.ar], División Paleobotánica, Facultad de Ciencias Naturales y Museo, Universidad Nacional de La Plata, CONICET, Paseo del Bosque s/n, (B1900FWA) La Plata, Buenos Aires, Argentina. 
This is an open-access article distributed under the terms of the Creative Commons

Attribution License (for details please see creativecommons.org), which permits unrestricted use, distribution, and reproduction in any medium, provided the original author and source are credited.

For Full text $(943.9 \mathrm{kB})$ 